\title{
Development of a TG-FTIR system for investigations with condensable and corrosive gases
}

\author{
M. Mehring $\cdot$ M. Elsener $\cdot$ O. Kröcher
}

ESTAC2010 Conference Special Issue

(C) Akadémiai Kiadó, Budapest, Hungary 2010

\begin{abstract}
A thermogravimetric analyzer and a Fouriertransform infrared (FTIR) spectrometer were combined and redesigned for investigations with corrosive and condensable reactive gases. The standard gas inlet and outlet of the thermogravimetric analyzer were changed in order to heat the gas tubes, which are lead through the flanges, and avoid condensation in these parts of the system. Furthermore, all tubes upstream and downstream of the thermogravimetric analyzer were trace heated up to $180{ }^{\circ} \mathrm{C}$. The gas measuring cell of the FTIR spectrometer was designed such that an optimum compromise between the small flow rates through the thermogravimetric analyzer and a short residence time of the gases in the gas measuring cell could be achieved. The gas supply allows the dosage of different gas compositions containing nitrogen, oxygen, water, $\mathrm{NH}_{3}$, and $\mathrm{NO}_{2}$, for example. The system was validated by analyzing the composition of a diesel particulate matter (PM) sample with a temperature-programmed desorption followed by oxidation (TPD/O) experiment, which showed good agreement with the established analysis methods. The reactivity of the PM sample was investigated by temperature-programmed oxidation (TPO) experiments with different reactive gas mixtures of oxygen, water, and $\mathrm{NO}_{2}$ in nitrogen. By adding $\mathrm{NO}_{2}$, the soot oxidation started at lower temperatures and the addition of water lead to a shift of the maxima of the carbon oxidation rates to lower temperatures. The ratio of formed $\mathrm{CO}_{2}$ and $\mathrm{CO}$ was shifted
\end{abstract}

10th European Symposium on Thermal Analysis and Calorimetry.

M. Mehring $\cdot$ M. Elsener $\cdot$ O. Kröcher $(\square)$

Paul Scherrer Institute, 5232 Villigen PSI, Switzerland

e-mail: oliver.kroecher@psi.ch

URL: http://ega.web.psi.ch/home.html to higher values by the addition of $\mathrm{NO}_{2}$ and water whereby the influence of water was much more pronounced.

Keywords TG-FTIR - Corrosive gases - Condensable gases - Soot oxidation - Catalyst investigations - Multicomponent gas analysis

\section{Introduction}

Thermogravimetry (TG) is an established technique for the characterization of materials and substances by monitoring the mass change of samples due to desorption in a flow of inert gas or due to adsorption, desorption, and reaction in reactive gases. In standard TG systems, however, the choice of the reactive gas is restricted because balance and furnace housing are temperature controlled to $22-25{ }^{\circ} \mathrm{C}$ to keep the precision and stability of the mass signal. Gas mixtures or components with dew points around RT cannot be used since they may condensate on the walls of the system and cause corrosion.

The full potential of TG with reactive gases can only be tapped, when the evolved gases are analyzed besides the monitoring of the mass change due to adsorption, desorption, and reaction. For the gas analysis, mass spectrometry (MS) [1-4] and Fourier-transform infrared (FTIR) spectroscopy [4-10] are established techniques. The advantage of MS is the possibility to detected infrared-inactive substances like oxygen and nitrogen as well as characteristic fragments of larger molecules, but the signal stability is relatively low and therefore the calibration has to be checked and repeated very often in order to obtain meaningful results. In comparison, FTIR spectroscopy excels by an outstanding long-term stability of the analysis signal and additionally a more robust hardware. Although several gas 
components are infrared-inactive, this technique is, hence, preferred for gas analysis, when signal stability, robustness and precision are the selection criteria. When a FTIR spectrometer is chosen for the coupling with a thermogravimetric device it is necessary to adapt the volume of the gas measuring cell to the small flow rates through the TG instrument in order to increase the gas exchange rates and to prevent peak broadening.

In the present article, we report about the development and test of a TG-FTIR system for the thermal analysis of substances with condensable and corrosive reactive gases and the quantitative analysis of the evolved gases. The system was particularly designed for material characterizations in exhaust catalysis, as the industrial analysis methods used in this field so far come to their limits, e.g., the amount of diesel particulate matter (PM) collected on filters from the exhaust pipe decreased significantly in the last years due to a step-wise reduction of the emission limits. Although the system was mainly developed for the investigation of exhaust catalysts and diesel PM, it opens new possibilities in many other research fields as well.

\section{Instrument development}

As a starting point for the development of the TG-FTIR system a TGA/DSC1 thermogravimetric analyzer (TG) from Mettler-Toledo and an Antaris IGS FTIR spectrometer from Thermo Fisher Scientific were coupled. For the gas-mixing unit, electronic mass flow controllers (MFC) from Brooks (model 5850S) were used and controlled by a LabView program written in-house (Fig. 1). In addition to

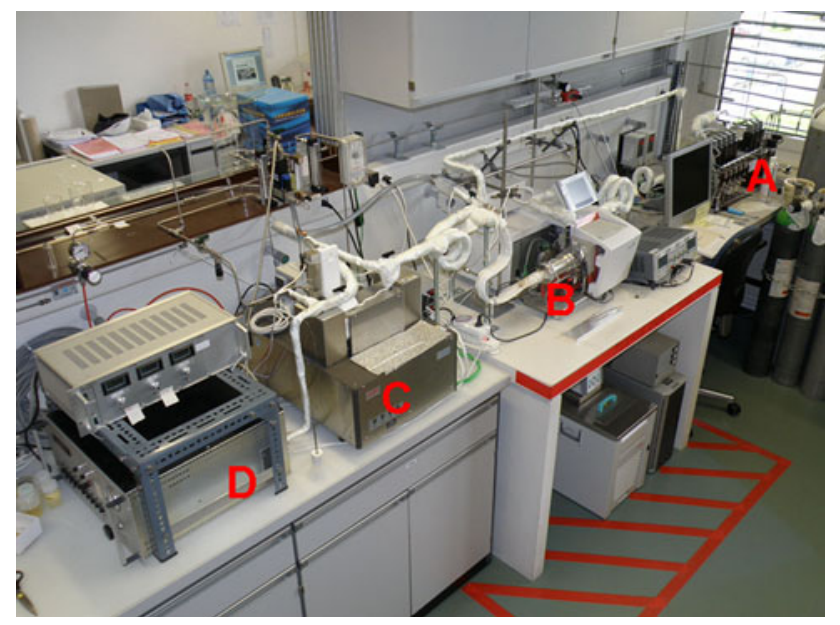

Fig. 1 Overview over the TG-FTIR system. A LabView-controlled gas-mixing unit with water generator; $B$ redesigned TGA/DSC 1 from Mettler-Toledo; $C$ FTIR spectrometer Antaris IGS from Thermo Fisher Scientific with the new gas measuring cell; and $D$ flame ionization detector (FID) the TG and the spectrometer, a flame ionization detector (FID) was installed downstream of the FTIR spectrometer in order to analyze desorbed hydrocarbons (HC) as described later.

\section{Gas-mixing unit}

The gas-mixing unit consisted of eight MFCs, which allow the dosage of seven different gas components beside the carrier gas nitrogen. Water was generated by controlled hydrogen oxidation in order to dose gaseous water without pulsation in the required range. A mixture of nitrogen as carrier gas, the right amount of hydrogen to produce the desired amount of water and oxygen in excess was dosed over a platinum catalyst heated to $400{ }^{\circ} \mathrm{C}$, where hydrogen was oxidized under controlled conditions. A flashback of the hydrogen flame was avoided by a sinter metal flame barrier after the mixing-point of oxygen and water. So far the water generator was tested for concentrations between some hundred ppm and 20\%, but higher concentrations should be possible. Nitrogen was dosed by a MFC in the range from 0 to $100 \mathrm{~mL} / \mathrm{min}$ at $\mathrm{STP}$, oxygen with a MFC between 0 and $25 \mathrm{~mL} / \mathrm{min}$ at STP, and hydrogen with a MFC from 0 to $10 \mathrm{~mL} / \mathrm{min}$ at STP.

Downstream of the water generator up to five other gas components could be dosed by MFCs in the range 0-10 $\mathrm{mL} / \mathrm{min}$ at $\mathrm{STP}$, which were $\mathrm{NO}, \mathrm{NO}_{2}, \mathrm{NH}_{3}, \mathrm{CO}_{2}$, and $\mathrm{CO}$ in our experiments. Since the target concentrations of the additional components were most often only in the ppm range they were dosed as mixtures in nitrogen ranging from $4,000 \mathrm{ppm}$ to $5 \%$. The total flow for standard experiments with the new system was $100 \mathrm{~mL} / \mathrm{min}$ at STP.

The gas-mixing unit was controlled by a LabView program written in-house. All flows were adapted automatically to new concentrations set-points conditions under consideration of purge and protection gas flows in order to keep a constant total gas flow of $100 \mathrm{~mL} / \mathrm{min}$ at STP. For safety reasons the hydrogen dosage range was restricted in the software.

All tubes downstream of the water generator were heated to $180{ }^{\circ} \mathrm{C}$ to reliably avoid condensation of reactants and products on the walls of the system.

\section{Thermogravimetric analyzer}

The TGA/DSC1 from Mettler-Toledo is a standard thermogravimetric analyzer for the temperature range from 25 to $1,100{ }^{\circ} \mathrm{C}$. In our study, it was equipped with a furnace for investigations of samples up to $5 \mathrm{~g}$ with a resolution of $0.1 \mu \mathrm{g}$. The protection gas flow through the balance was $30 \mathrm{~mL} / \mathrm{min}$ at STP. The dew points of the used reactive gases have to be well below RT since the gas is fed through the flange between the temperature controlled balance and 


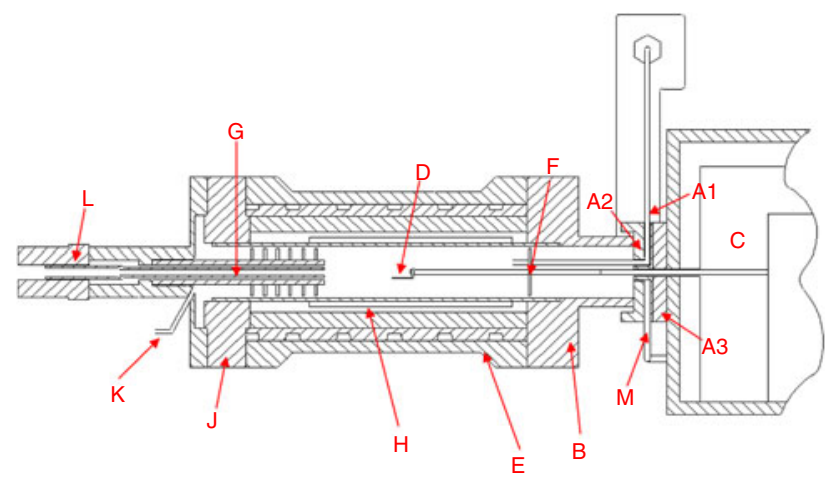

Fig. 2 Mechanical drawing of a cut through the redesigned TG. $A$ new inlet flange; $A 1$ resistance wire-heated gas tube; $A 2$ front part of the new inlet flange; $A 3$ back part of the new inlet flange; $B$ right furnace flange to balance; $D$ sample holder; $E$ furnace; $F$ ceramic disk for backflow prevention; $G$ heated quartz glass gas outlet in ceramic tube; $H$ furnace heating elements; $J$ left furnace flange; $K$ purge gas inlet for the prevention of condensation in the gas outlet and the left furnace flange; $L$ gas tube fitting for the connection of the transfer line between TG furnace and FTIR spectrometer; and $M$ purge gas inlet for the prevention of condensation at the front wall of the inlet flange

furnace housing at $25{ }^{\circ} \mathrm{C}$. Therefore, mixtures of water, ammonia, and $\mathrm{NO}_{2}$ for the investigation of diesel exhaust catalysts and PM could not be dosed. In order to overcome this problem, the flange between balance and furnace, where the gases enter the furnace, was replaced by an inhouse redesigned flange with trace-heated gas tubes. In Fig. 2, a mechanical drawing of the TG with the new inlet flange is shown.

The gas inlet flange A in Fig. 2 was made from stainless steel and consists of three parts: the trace-heated gas tube A1, the front part of the inlet flange A2, and the back part of the flange. The heated gas tube was placed in a duct in front part A2 and the back part A3 was screwed on the front part in order to fix the heated gas tube. All fittings were sealed by O-rings. Additional to the reactive gas inlet a purge gas inlet $\mathrm{M}$ for the dosage of $5 \mathrm{~mL} / \mathrm{min}$ nitrogen at STP was installed at the bottom of the inlet flange. Through six holes $(\varnothing=1.6 \mathrm{~mm})$ the flow entered the TG furnace to avoid condensation on the front surface of the flange. The tube for the reactive gases was heated up to the ceramic disk $\mathrm{F}$ in Fig. 2. The disk minimized the back flow of reactive gas to the inlet flange. On the sample holder $\mathrm{D}$ the PM sample was placed on a quartz glass disk instead of a crucible in order to avoid mass transport limitations. The gases which desorbed from the sample left the furnace through the left furnace flange $\mathrm{J}$, which was redesigned as well. In the ceramic tube a resistance-heated quartz glass capillary $\mathrm{G}$ was placed and additionally the purge gas inlet $\mathrm{K}$ for the dosage of $5 \mathrm{~mL} / \mathrm{min}$ nitrogen at STP was installed. By these measures and the ceramic disk F on the ceramic tube any condensation was avoided. The TG outlet was connected to the gas transfer line to the FTIR spectrometer by a glass-to-metal connection (Swagelok).

Figure 3 shows the temperature profiles measured over the length of the gas inlet and outlet. The profile of the inlet was very stable and varied only little over the tube. The profile of the outlet was more unstable on the first view, but the zone between 0 and $2 \mathrm{~cm}$ was additionally heated during operation by the trace heating of the transfer line to the spectrometer and the region around $8 \mathrm{~cm}$ was close to the sample holder and heated by the furnace atmosphere during operation.

\section{FTIR spectrometer}

The FTIR spectrometer for the gas analysis was connected to the TG apparatus via a corrugated tube (DN4) as transfer line, which was heated to $180{ }^{\circ} \mathrm{C}$ by trace heating. The standard gas measuring cell of the Antaris IGS Spectrometer has a volume of $240 \mathrm{~mL}$ and a path length of $2 \mathrm{~m}$. The gas flow of only $100 \mathrm{~mL} / \mathrm{min}$ at STP through the TG resulted in too low gas exchange rates in the measuring cell, which affected the time resolution. Therefore, the size and shape of the spectrometer gas cell had to be optimized with the objective to find a compromise between small flow rates, which were necessary to get sufficiently high gas concentrations for the detection of even small concentration changes, and a short residence time, which was needed to prevent peak broadening. These goals were reached by a newly designed measuring cell from Thermo Fisher Scientific with a path length of $178 \mathrm{~mm}$ and without optics for the reflexion of the IR beam. By this measure the time for IR absorption of the evolved gas becomes smaller, but peak broadening is avoided at the same time. In addition, the cell

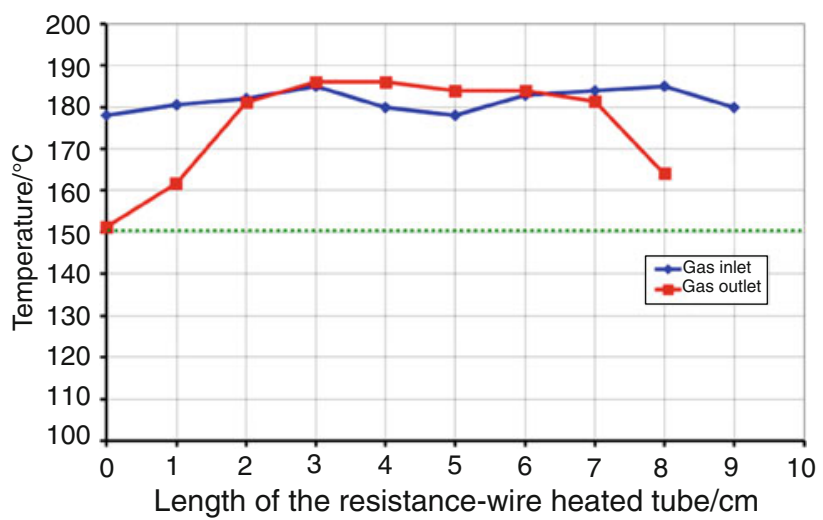

Fig. 3 Temperature profiles of the resistance wire heated gas in- and outlet. Doted line: minimum temperature for condensation prevention. The temperature drop between 0 and $2 \mathrm{~cm}$ is due to the end of the resistance wire heated zone. During system operation this part was heated by the trace heating of the transfer line to the spectrometer. The drop at $8 \mathrm{~cm}$ shows the end of the heating wire in the furnace close to the sample holder 
volume was reduced to further improve the transfer rates. The typical cylindric shape of the cell was constricted in the middle, which complies with the shape of the uncollimated beam. The measuring cell looks like two cones lying with their tips in opposite to each other (Fig. 4), so that the IR beam fills the cell completely and any dead volume is avoided. On the first view, the reduction of the path length by a factor of 10 should degrade the detection limits as well by a factor of 10 , but since the IR beam in the new cell does not loose energy due to reflexions, the detection limits are only $2.5-3$ worse than those of the standard cell depending on the gas component.

The FTIR spectrometer was calibrated for $\mathrm{NO}, \mathrm{NO}_{2}$, $\mathrm{NH}_{3}, \mathrm{CO}_{2}, \mathrm{CO}, \mathrm{H}_{2} \mathrm{O}, \mathrm{SO}_{2}, \mathrm{~N}_{2} \mathrm{O}, \mathrm{HCN}, \mathrm{HNCO}$, formic acid, and formaldehyde, which are typical components of engine exhaust gases. The infrared spectrometer of Thermo Fisher Scientific was chosen for this project, because the spectrometer software Omnic allows the development and calibration of multi-component gas analysis methods, in which cross-sensitivities can be compensated. Table 1 shows an overview of the detection limits of the Antaris IGS spectrometer with the new gas measuring cell.

\section{Flame ionization detector}

Downstream of the FTIR spectrometer a FID was installed for the measurement of the desorbed HC from the PM samples. At first it was tried to analyze the $\mathrm{HC}$ with the FTIR spectrometer, but the number of different HC adsorbed on PM were too high to calibrate them all. And the calibration of the $-\mathrm{CH}_{2}-$ group signal, which is similar for all $\mathrm{HC}$, was not possible since this group has different adsorption coefficients at different wave lengths for different HC.

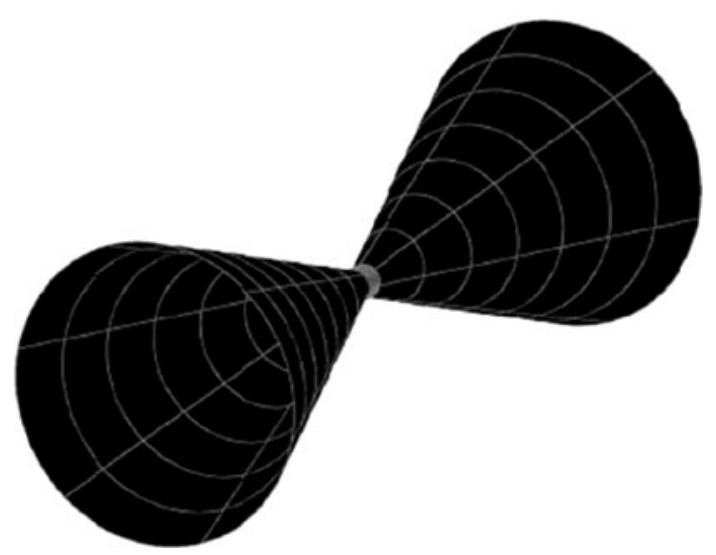

Fig. 4 Scheme of the inner shape of the gas measuring cell with a path length of $178 \mathrm{~mm}$. The shape of the uncollimated IR beam is similar and therefore fills the gas cell completely. By this measure any dead volume is avoided and the detection limits of the $2 \mathrm{~m}$ standard gas cell are nearly reached
Table 1 Detection limits of the FTIR spectrometer

\begin{tabular}{lll}
\hline Component & Detection limit/ppm & Standard deviation \\
\hline $\mathrm{CO}$ & 1 & \pm 1.0 \\
$\mathrm{CO}_{2}$ & 0.6 & \pm 0.6 \\
$\mathrm{H}_{2} \mathrm{O}$ & 5 & \pm 4.5 \\
Formic acid & 0.5 & \pm 0.5 \\
Formaldehyde & 2.1 & \pm 2.1 \\
$\mathrm{NO}_{2}$ & 1 & \pm 0.8 \\
$\mathrm{SO}_{2}$ & 0.5 & \pm 0.5 \\
$\mathrm{NO}$ & 3.2 & \pm 3.1 \\
$\mathrm{NH}_{3}$ & 1 & \pm 0.9 \\
$\mathrm{HNO}_{3}$ & 1.5 & \pm 1.1 \\
$\mathrm{HNCO}$ & 0.5 & \pm 0.5 \\
$\mathrm{HCN}$ & 3 & \pm 2.8 \\
$\mathrm{~N}_{2} \mathrm{O}$ & 0.6 & \pm 0.6 \\
\hline
\end{tabular}

\section{Applications of the TG-FTIR system}

The option to use condensable and corrosive reactive gases is a pre-requisite for many thermal analysis applications in different research fields, from which the analysis of diesel PM has been selected.

The composition of the PM samples were analyzed by so-called temperature-programmed desorption followed by oxidation (TPD/O) experiments. During such experiments the samples were heated first under inert conditions (here: nitrogen atmosphere) to $700{ }^{\circ} \mathrm{C}$ with $20 \mathrm{~K} / \mathrm{min}$ in order to decompose thermally unstable oxygen surface functional groups like carboxyls, carbonyls, etc. (which decompose into $\mathrm{CO}$ and $\mathrm{CO}_{2}$ ) as well as to desorb unburned $\mathrm{HC}$, water, adsorbed sulfuric acid, and some nitrogen containing components. Together with the surface functional groups, the adsorbed $\mathrm{HC}$ form the organic carbon (OC) fraction of the PM. After the samples had reached $700{ }^{\circ} \mathrm{C}$, they were cooled down to $300{ }^{\circ} \mathrm{C}$ with $-20 \mathrm{~K} / \mathrm{min}$ and heated up again to $750{ }^{\circ} \mathrm{C}$ at $20 \mathrm{~K} / \mathrm{min}$ with $10 \%$ oxygen in the feed gas to oxidize the elemental carbon (EC), which consists of graphitic-like structures, to $\mathrm{CO}$ and $\mathrm{CO}_{2}$ plus other components which desorb only under oxidizing conditions. From the amount of water, evolved during the oxidation part, the hydrogen content of the sample could be calculated. The amount of the residuals after the experiments consisting of metal oxides and sulfates from combusted lubrication oil and fuel additives as well as from engine abrasion was quantified by the mass signal of the TG.

Beside these TPD/O experiments, the TG-FTIR system is also suitable for reactivity tests, in which samples are exposed to reactive gas mixture to mimic the behavior of samples under real-world conditions. In the field of PM 
analysis, we performed temperature-programmed oxidation (TPO) experiments with diesel soot samples using condensable and corrosive reactive gases.

In our TPO experiments, the samples were usually heated from 50 to $750{ }^{\circ} \mathrm{C}$ at $10 \mathrm{~K} / \mathrm{min}$ in a feed of $10 \%$ oxygen, $5 \%$ water, and $1,000 \mathrm{ppm} \mathrm{NO}_{2}$ in nitrogen. The optimum sample size was above or equal $300 \mu \mathrm{g}$ to obtain the full set of information from the TG and the spectrometer. From the ratio of $\mathrm{CO}_{2}$ and $\mathrm{CO}$ in the product gas and the comparison of the mass loss signal with the concentrations of formed gas components the ongoing reactions during the regeneration of diesel particulate filter (DPF) systems could be separated.

\section{Results}

The functionality of the TG-FTIR system was validated by means of the reactivity analysis of a powder PM sample generated by a modern diesel engine (herein after referred to as sample A) with four different reactive gas compositions. Figure 5 shows the results of the composition analysis of the OC, EC, and metal ash content by the TPD/O method described in the previous section (Fig. 5a) in comparison to the results of an external analysis of the same sample (Fig. 5b). The agreement between both analyses is good, whereas the difference in the ash content is due to sample inhomogeneities. The difference in the OC and EC content can result from inhomogeneities, too, or from a different positioning of the OC/EC split. Table 2 shows a summary of the results for each detectable component of the TPD/O analysis at PSI. The EC is the component with the highest concentration, followed by water, oxygen, and OC. Sulfates and nitrogen containing compounds were found only in traces. Adding the mass of each component measured by the FTIR spectrometer plus the ash content gives $100.9 \%$ of the initial mass, which confirms the accuracy of the method.

After the TPD/O analysis of sample A, its reactivity was tested with four different gas compositions (Table 3). The base feed was a flow of $100 \mathrm{~mL} / \mathrm{min}$ nitrogen with $10 \%$ oxygen at STP. In the first experiment the base feed was used (exp. 1) and in the second experiment 5\% water were added (exp. 2). For the third experiment, 1,000 ppm of $\mathrm{NO}_{2}$ were dosed additionally (exp. 3) and in the fourth experiment the base feed was mixed with 1,000 ppm $\mathrm{NO}_{2}$ and $5 \%$ water (exp. 4).

Figure 6 shows the mass loss of the samples in percent of the initial mass plotted over temperature. In the temperature range up to $300{ }^{\circ} \mathrm{C}$, no significant difference between the curves can be observed and therefore $\mathrm{OC}$ desorption is supposed to be responsible for the mass loss. At $300{ }^{\circ} \mathrm{C}$, the mass decreases significantly for the experiments with $\mathrm{NO}_{2}$ in the feed gas due to $\mathrm{NO}_{2}$ oxidation of the carbon. In addition, a small difference between the experiments with dry and humid feed gas is discernible, whereby the influence of water was even stronger when cofed with $\mathrm{NO}_{2}$. The onset-temperature of soot oxidation by oxygen was $540{ }^{\circ} \mathrm{C}$ and the mass decreased fast at higher temperatures. In the presence of both oxygen and $\mathrm{NO}_{2}$, there is a transition between both oxidation regimes, which makes the start of the soot oxidation by oxygen less clear defined compared to an oxygen-only feed. The curve crossing at $600{ }^{\circ} \mathrm{C}$ shows the growing influence of water in

Table 2 Summary of the TPD/O analysis results of sample A at PSI in wt $\%$ of the initial mass, in $\mathrm{mg}$, and in mmol

\begin{tabular}{lccc}
\hline & \multicolumn{2}{c}{ Initial mass $1.492 \mathrm{mg}$} & \\
\cline { 2 - 4 } & $\mathrm{wt} \%$ & $\mathrm{mg}$ & $\mathrm{mmol}$ \\
\hline $\mathrm{EC}$ & 76.0 & 1.134 & 13.607 \\
$\mathrm{OC}$ & 5.4 & 0.081 & 0.967 \\
$\mathrm{SO}_{4}{ }^{2-}$ & 0.1 & 0.001 & 0.143 \\
$\mathrm{~N}$ & 0.2 & 0.003 & 0.042 \\
$\mathrm{O}$ & 8.0 & 0.119 & 1.910 \\
$\mathrm{H}$ & 0.2 & 0.004 & 0.004 \\
$\mathrm{Water}$ & 8.0 & 0.119 & 2.148 \\
Ash & 3.0 & 0.045 & - \\
Sum & 100.9 & 1.506 & 18.821 \\
\hline
\end{tabular}

Table 3 Composition of the gas mixtures used for the TPO investigations of sample A

\begin{tabular}{lllll}
\hline & $\mathrm{N}_{2} / \%$ & $\mathrm{O}_{2} / \%$ & $\mathrm{NO}_{2} / \%$ & $\mathrm{H}_{2} \mathrm{O} / \%$ \\
\hline Exp. 1 & 85 & 10 & 0 & 0 \\
Exp. 2 & 85 & 10 & 0 & 5 \\
Exp. 3 & 89.9 & 10 & 0.1 & 0 \\
Exp. 4 & 84.9 & 10 & 0.1 & 5 \\
\hline
\end{tabular}

Fig. 5 OC, EC, and ash content determined by a TPD/O analysis of sample A at PSI (a) and by standard analysis methods in an external lab (b) a

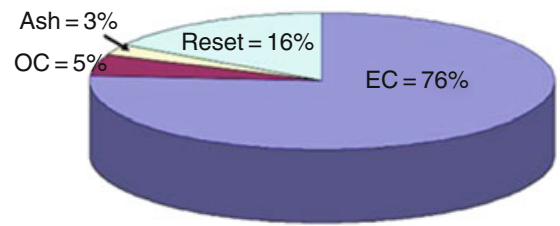

b

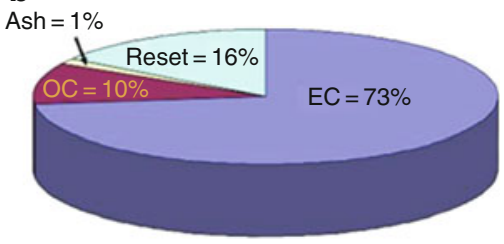




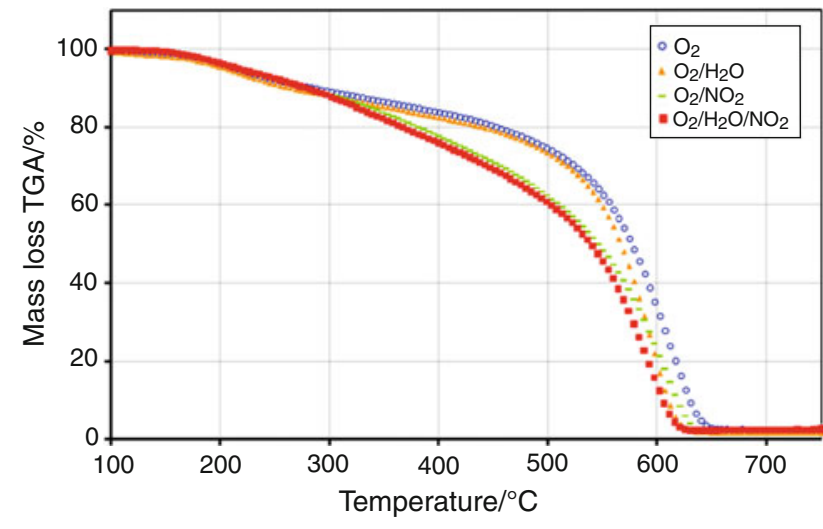

Fig. 6 Mass loss curves during the TPO of sample A with four different gas compositions

this temperature region and the decreasing influence of $\mathrm{NO}_{2}$. With $\mathrm{NO}_{2}$ and water in the feed, the soot was completely oxidized at $620^{\circ} \mathrm{C}$, while $627^{\circ} \mathrm{C}$ was required, when only water was added. The oxidation reaction was completed at $637{ }^{\circ} \mathrm{C}$ for the experiment with $\mathrm{NO}_{2}$ and at $647{ }^{\circ} \mathrm{C}$, when only the base feed was dosed.

Figure 7 shows the concentrations of $\mathrm{CO}$ and $\mathrm{CO}_{2}$ for all tests, measured with FTIR spectroscopy. In general, the observations from Fig. 6 are confirmed by the graphs in Fig. 7, but due to the much higher sensitivity of the FTIR signal compared to the mass signal, the features are much more pronounced and the differences are more clearly visible. Already for temperatures $<200{ }^{\circ} \mathrm{C}$, a small difference between the experiments with and without $\mathrm{NO}_{2}$ can be determined, which is even more pronounced in the recalculated representation of the data in Fig. 9. This shows that up to $300{ }^{\circ} \mathrm{C} \mathrm{NO}$ oxidation of soot runs in parallel with the desorption of $\mathrm{OC}$ for the experiments with $\mathrm{NO}_{2}$ in the feed gas and for the experiments without $\mathrm{NO}_{2}$, only OC desorption accounts for the C-oxidation rate. Furthermore, Fig. 7 shows again the influence of water by the shift of the peak maxima of $\mathrm{CO}$ and $\mathrm{CO}_{2}$ to lower temperatures for the experiments with humid feed gas. The $\mathrm{CO}_{2} / \mathrm{CO}$ ratios in Fig. 8, which can be calculated from the data shown in Fig. 7 for each measuring point, reveal important information about the reaction mechanism, since a difference or change of that ratio is an indicator for the underlying oxidation mechanism of the investigated soot. The addition of water and $\mathrm{NO}_{2}$, for example, increases the $\mathrm{CO}_{2} / \mathrm{CO}$ ratio in Fig. 8 significantly. The characteristics of the curves for the experiments with $\mathrm{NO}_{2}$ in the feed gas are similar, but the ratios are shifted to higher values by the addition of water and the samples treated without $\mathrm{NO}_{2}$ show a similar behavior.

The C-oxidation rates in Fig. 9 show beside the influence of water and $\mathrm{NO}_{2}$ that in the temperature range between 300 and $500{ }^{\circ} \mathrm{C}$ the $\mathrm{C}$-oxidation rates flatten out
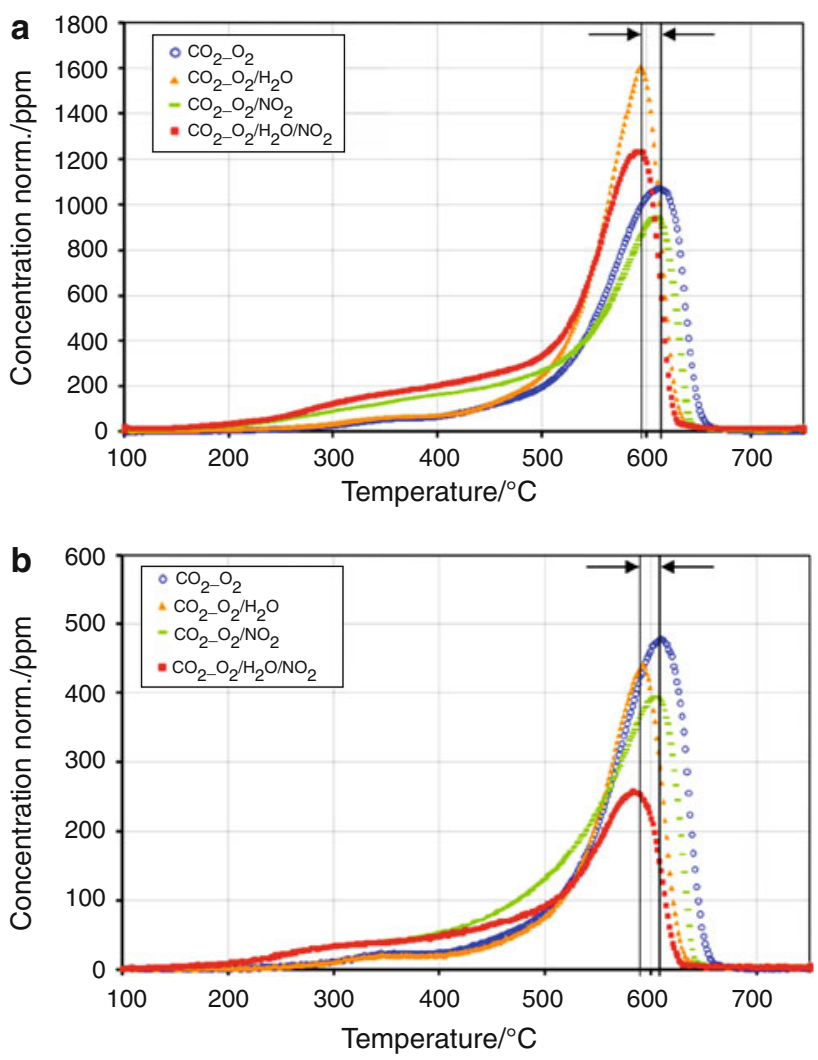

Fig. 7 FTIR signals of $\mathrm{CO}_{2}$ (a) and $\mathrm{CO}$ (b) during the TPO analysis of sample A with four different gas compositions. The arrows indicate the temperature shift due to water dosage

for the experiments with $\mathrm{NO}_{2}$ due to diffusion limitation of $\mathrm{NO}_{2}$. For the experiments without $\mathrm{NO}_{2}$ the oxidation rates flatten out between 300 and $400{ }^{\circ} \mathrm{C}$, since $\mathrm{OC}$ desorption is nearly finished and the oxidation has not started yet.

\section{Discussion}

PM oxidation with $\mathrm{O}_{2}$ and $\mathrm{O}_{2} / \mathrm{NO}_{2}$

The results obtained for the oxidation of sample A with different reactive gas compositions are in agreement with the results reported in the literature. The general soot oxidation mechanism is assumed to be similar for all used oxidants: first an oxygen atom is transferred from the gas phase to the soot surface forming an oxygen surface functional group as intermediate, which then decomposes on heating into $\mathrm{CO}$ or $\mathrm{CO}_{2}$ thereby removing a carbon atom from the soot surface [11]. The formed surface functional groups are carboxylic acids, lactones, anhydrides, carbonyls, phenols and ethers [12] plus $\mathrm{R}-\mathrm{NO}_{2}$, and $\mathrm{R}-\mathrm{ONO}$ in the presence of $\mathrm{NO}_{2}$ [13]. In the presence of $\mathrm{NO}_{2}$ more carboxylic acids and lactones are formed, which decompose at lower temperatures in comparison to those 


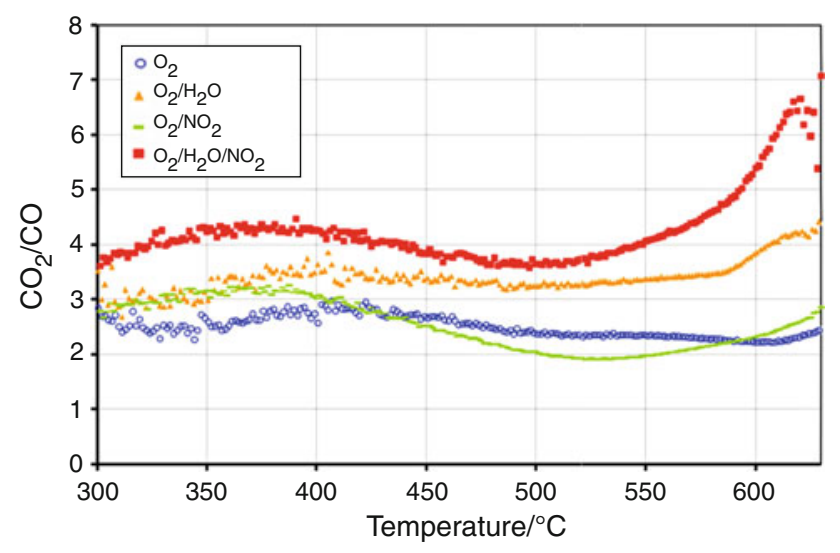

Fig. $8 \mathrm{CO}_{2} / \mathrm{CO}$ ratios versus temperature calculated from the data in Fig. 7 for the different gas compositions

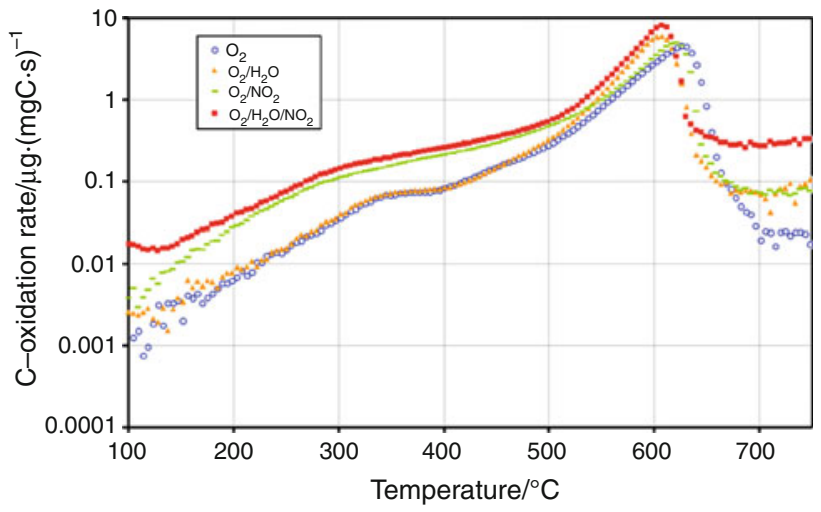

Fig. 9 C-oxidation rates during the TPO of sample A with four different gas compositions, calculated from the data in Fig. 7

formed in the presence of $\mathrm{O}_{2}$, explaining the higher reactivity of $\mathrm{NO}_{2}[11,14]$.

When $\mathrm{NO}_{2}$ and $\mathrm{O}_{2}$ were dosed in parallel in this study (exp. 3 and 4 in Table 3) an increase of the oxidation rate in comparison to the rate in exp. 1 and 2 (Table 3) was observed. This can be explained by a co-operative oxidation reaction proposed by Setiabudi et al. [11], in which first the more reactive $\mathrm{NO}_{2}$ forms surface intermediates, which react with $\mathrm{O}_{2}$ or $\mathrm{NO}_{2}$ in a second step to release $\mathrm{CO}$ or $\mathrm{CO}_{2}$.

Another possible explanation was given by Jeguirim et al., who proposed that both $\mathrm{O}_{2}$ and $\mathrm{NO}_{2}$ can form surface functional groups, which afterward react with $\mathrm{NO}_{2}$ releasing $\mathrm{CO}$ and $\mathrm{CO}_{2}$ according to the overall reactions (1) and (2) [15]. In reaction (2), $\mathrm{NO}_{2}$ is indirectly involved and acts as a catalyst.

$\mathrm{C}+1 / 2 \mathrm{O}_{2}+\mathrm{NO}_{2} \rightarrow \mathrm{CO}_{2}+\mathrm{NO}$

$\mathrm{C}+1 / 2 \mathrm{O}_{2} \stackrel{\mathrm{NO}_{2}}{\longrightarrow} \mathrm{CO}$

From the results in this study it was not possible to decide, which of the suggested mechanisms occurs on the investigated sample. Both pathways are in agreement with the obtained data and it might be possible that they occur in parallel.

Influence of water on the PM oxidation with $\mathrm{O}_{2}$ and $\mathrm{O}_{2} / \mathrm{NO}_{2}$

The addition of water shifted the TG profiles (Fig. 6) and the maxima of the oxidation rates (Fig. 9) to lower temperatures. Several feasible reaction mechanisms are proposed in the literature to explain this influence, but a final explanation has not been found yet. On the first view, the direct oxidation of soot by water does not seem to play an important, since the oxidation with oxygen is $10^{4}$ times faster [16], but Ahlström et al. assumed that this reaction might be accelerated by the fast removal of strongly adsorbed hydrogen by oxygen, so that the next water molecule can attack the carbon surface [17]. Furthermore, it is assumed that water changes the structure of the soot surface, as known from the production of active carbon from carbonaceous materials by steam treatment $[17,18]$. Finally, Neeft et al. proposed an influence of water on the stability of the oxygen surface functional groups [18], which could also explain the observed promoting effect of water.

A further increase of the oxidation rates was observed in exp. 4, in which $\mathrm{NO}_{2}$ was added to the feed gas containing $\mathrm{O}_{2}$ and water. When water and $\mathrm{NO}_{2}$ are dosed in parallel $\mathrm{HNO}_{3}$ and $\mathrm{HNO}_{2}$ are formed in a disproportionation reaction [15, 19-21]. Jeguirim et al. suggested, supported by experimental and theoretical results, that $\mathrm{HNO}_{3}$ and $\mathrm{HNO}_{2}$ are intermediates of the $\mathrm{C}-\mathrm{NO}_{2}$ reaction, which can hence directly react with the carbon surface leading to an increase of the reaction rate [15].

\section{$\mathrm{CO}_{2} / \mathrm{CO}$ ratios}

As has been mentioned, the $\mathrm{CO}_{2} / \mathrm{CO}$ ratio acts as an indicator for changes in the reaction mechanism. In Fig. 8, the $\mathrm{CO}_{2} / \mathrm{CO}$ ratio are plotted over temperature showing that a change of the reactive gas composition has a direct influence on the evolution of $\mathrm{CO}_{2}$ and $\mathrm{CO}$. In the presence of water, the ratio increases significantly over the whole temperature range as exemplified by exp. 1 and 2 as well as exp. 3 and 4. This increase seems to be caused by the water-gas shift reaction (WGS) occurring on the soot surface $[17,18,22]$, which converts part of the primary produced $\mathrm{CO}$ to $\mathrm{CO}_{2}$ :

$\mathrm{CO}+\mathrm{H}_{2} \mathrm{O} \rightarrow \mathrm{CO}_{2}+\mathrm{H}_{2}$ (WGS)

Furthermore, the $\mathrm{CO}_{2} / \mathrm{CO}$ ratio is influenced by the presence of $\mathrm{NO}_{2}$. In the temperature range up to $380{ }^{\circ} \mathrm{C}$ the ratio increases due to an increased formation of carboxylic groups and lactones, which decompose to $\mathrm{CO}_{2}$ and water 
[12], so that the $\mathrm{CO}_{2} / \mathrm{CO}$ ratio of the $\mathrm{O}_{2} / \mathrm{NO}_{2}$ experiment reaches the same level as in the $\mathrm{O}_{2} / \mathrm{H}_{2} \mathrm{O}$ experiment. At $380{ }^{\circ} \mathrm{C}$, the $\mathrm{CO}_{2} / \mathrm{CO}$ ratio decreases for exp. 3 and 4 probably due to a diffusion limitation of $\mathrm{NO}_{2}$, which was also responsible for the flattening of the $\mathrm{C}$-oxidation rates in Fig. 9. One can speculate that reaction (2) [15] becomes the main reaction for the decomposition of oxygen surface complexes, when $\mathrm{NO}_{2}$ is depleted on the sample surface, leading to an increase of $\mathrm{CO}$ evolution. When the temperature was further increased the $\mathrm{CO}_{2} / \mathrm{CO}$ ratio increased again due to the increase of the $\mathrm{NO}_{2}$ diffusion rates and the start of the soot oxidation by oxygen.

\section{Conclusions and outlook}

In the project a TG-FTIR system was set up, which allows to investigate different materials and substances with reactive gas mixtures. The developed prototype system was based on a standard thermogravimetric analyzer, whose inlet and outlet parts were reconstructed to prevent condensation and corrosion. Moreover, a special FTIR gas measuring cell was designed with a path length of $178 \mathrm{~mm}$ and a volume of $<40 \mathrm{~mL}$, which showed a high signal-tonoise ratio and a short residence time even for small flow rates through the system.

The performance of the system was tested using the example of diesel PM analysis. A TPD/O method was developed that allowed to analyze $300 \mu \mathrm{g}$ PM samples concerning EC, OC, ash content, oxygen, hydrogen, adsorbed sulfuric acid, and some nitrogen containing species. Furthermore, the reactivity of a PM sample was investigated under real-world conditions by TPO analyses with different reactive gas compositions showing good agreement with results reported in the literature. So far, $\mathrm{O}_{2}$, $\mathrm{H}_{2} \mathrm{O}, \mathrm{NH}_{3}, \mathrm{NO}_{2}$, and $\mathrm{NO}$, separately or in mixtures, were tested as gas components, but other mixtures seem to be possible as well.

With the new TG-FTIR system it is planned to further improve the reactivity investigations of PM samples in order to learn about the kinetics and the reaction mechanism of soot oxidation with different reactive gases.

Acknowledgements We acknowledge U. Jörimann and M. Schubnell from Mettler-Toledo as well as A. Möps, H. Belz, and D. Hohler from Thermo Fisher Scientific for technical help and support.

\section{References}

1. Madarász J, Kaneko S, Okuya M, Pokol G. Comparative evolved gas analyses of crystalline and amorphous titanium(IV)oxohydroxo-acetylacetonates by TG-FTIR and TG/DTA-MS. Thermochim Acta. 2009;489(1-2):37-44.
2. Madarász J, Varga PP, Pokol G. Evolved gas analyses (TG/DTAMS and TG-FTIR) on dehydration and pyrolysis of magnesium nitrate hexahydrate in air and nitrogen. J Anal Appl Pyrol. 2007; 79(1-2):475-8.

3. Qu H, Wu W, Wu H, Xie J, Xu J. Study on the effects of flame retardants on the thermal decomposition of wood by TG-MS. J Therm Anal Calorim. 2010. doi:10.1007/s10973-010-1103-3.

4. Wyrzykowski D, Hebanowska E, Nowak-Wiczk G, Makowski M, Chmurzyński L. Thermal behaviour of citric acid and isomeric aconitic acids. J Therm Anal Calorim. 2010. doi:10.1007/s 10973-010-1015-2.

5. Etienne S, Becker C, Ruch D, Germain A, Calberg C. Synergetic effect of poly(vinyl butyral) and calcium carbonate on thermal stability of poly(vinyl chloride) nanocomposites investigated by TG-FTIR-MS. J Therm Anal Calorim. 2010;100(2):667-77.

6. Mocanu A, Odochian L, Apostolescu N, Moldoveanu C. Comparative study on thermal degradation of some new diazoaminoderivatives under air and nitrogen atmospheres. J Therm Anal Calorim. 2010;100:615-22.

7. Plante AF, Fernández JM, Leifeld J. Application of thermal analysis techniques in soil science. Geoderma. 2009;153(1-2): $1-10$.

8. Souza B, Moreira A, Teixeira A. TG-FTIR coupling to monitor the pyrolysis products from agricultural residues. J Therm Anal Calorim. 2009;97(2):637-42.

9. Tao L, Zhao G-B, Qian J, Qin Y-k. TG-FTIR characterization of pyrolysis of waste mixtures of paint and tar slag. J Hazard Mater. 2010;175(1-3):754-61.

10. Xu T, Huang X. A TG-FTIR investigation into smoke suppression mechanism of magnesium hydroxide in asphalt combustion process. J Anal Appl Pyrol. 2010;87(2):217-23.

11. Setiabudi A, Makkee M, Moulijn JA. The role of $\mathrm{NO}_{2}$ and $\mathrm{O}_{2}$ in the accelerated combustion of soot in diesel exhaust gases. Appl Catal B. 2004;50(3):185-94.

12. Muckenhuber $\mathrm{H}$, Grothe $\mathrm{H}$. The heterogeneous reaction between soot and $\mathrm{NO}_{2}$ at elevated temperature. Carbon. 2006;44(3): 546-59.

13. Muckenhuber $\mathrm{H}$, Grothe $\mathrm{H}$. A drifts study of the heterogeneous reaction of $\mathrm{NO}_{2}$ with carbonaceous materials at elevated temperature. Carbon. 2007;45(2):321-9.

14. Jeguirim M, Tschamber V, Brilhac JF, Ehrburger P. Interaction mechanism of $\mathrm{NO}_{2}$ with carbon black: effect of surface oxygen complexes. J Anal Appl Pyrol. 2004;72(1):171-81.

15. Jeguirim M, Tschamber V, Brilhac JF, Ehrburger P. Oxidation mechanism of carbon black by $\mathrm{NO}_{2}$ : effect of water vapour. Fuel. 2005;84(14-15):1949-56.

16. Matsui K, Tsuji H, Makino A. Estimation of the relative rates of the $\mathrm{C}-\mathrm{O}_{2}$ and the $\mathrm{C}-\mathrm{H}_{2} \mathrm{O}$ reactions. Carbon. 1983;21(3):320-1.

17. Ahlström AF, Odenbrand CUI. Combustion characteristics of soot deposits from diesel engines. Carbon. 1989;27(3):475-83.

18. Neeft JPA, Nijhuis TX, Smakman E, Makkee M, Moulijn JA. Kinetics of the oxidation of diesel soot. Fuel. 1997;76(12): 1129-36.

19. Jacquot F, Logie V, Brilhac JF, Gilot P. Kinetics of the oxidation of carbon black by $\mathrm{NO}_{2}$ : influence of the presence of water and oxygen. Carbon. 2002;40(3):335-43.

20. Kong $\mathrm{Y}$, Cha $\mathrm{CY} . \mathrm{NO}_{\mathrm{x}}$ adsorption on char in presence of oxygen and moisture. Carbon. 1996;34(8):1027-33.

21. Richter E, Kleinschmidt R, Pilarczyk E, Knoblauch K, Jüntgen H. Thermal desorption of nitrogen oxides from activated carbon. Thermochim Acta. 1985;85:315-8.

22. Messerer A, Niessner R, Poschl U. Comprehensive kinetic characterization of the oxidation and gasification of model and real diesel soot by nitrogen oxides and oxygen under engine exhaust conditions: measurement, Langmuir-Hinshelwood, and Arrhenius parameters. Carbon. 2006;44(2):307-24. 